\title{
STANDARDIZATION OF SOAKING TREATMENTS FOR SINGLE SEEDED PODS OF GROUNDNUT CV. CO 2 FOR ENHANCING SEED QUALITY
}

\author{
A. USHA* ${ }^{*}$ R. JERLIN \& J. RENUGADEVI \\ Department of Seed Science and Technology, Tamil Nadu Agricultural University,
}

Coimbatore, Tamil Nadu, India

\begin{abstract}
The present study was undertaken to study whether the single seeded pods of groundnut can be used as seed without shelling and its effect on different soaking treatments in improving seed quality parameters of cv. CO 2. The single seeded pods were soaked in different solutions viz., distilled water, calcium chloride (0.5\%, $1 \%$ and $2 \%)$ and ethrel (200ppm and 400ppm) for various durations of 12, 24 and 36 hrs. The single seeded pods without soaking treatment served as control. The maximum seed quality parameters viz., germination per cent, speed of germination, root length, shoot length, dry matter production, vigour index I and vigour index II were recorded from the pods soaked in $1 \%$ calcium chloride for 36 hrs.
\end{abstract}

KEYWORDS: Groundnut, Single Seeded Pods, Calcium Chloride \& Improved Germination

Received: Mar 26, 2019; Accepted: Apr 16, 2019; Published: May 10, 2019; Paper Id.: IJASRJUN201932

\section{INTRODUCTION}

Groundnut (Arachis hypogaea.L,) is an economically important oilseed crop also called as monkey nut, peanut and goober. It is the $13^{\text {th }}$ important food crop in the world and first crucial oilseed crop in India. It is a major source of edible oil and vegetable protein hence it is often known as King of oilseeds. The groundnut is an excellent plant based source of protein (25-36\%) and vegetable oil (47-53\%) (Jeyaraman, 2017).

In India, the groundnut is mostly grown in kharif season ( $85 \%$ area) under rain-fed condition. Thus the groundnut production and productivity is associated with the amount and distribution of precipitation. However achieving the stable yield in groundnut production is still a lagging one. Their low productivity is due to biotic and abiotic stresses in varied space and time (Nigam, 2000). In addition to that, the flowering pattern in groundnut affects the production. Only $20 \%$ of flowers produced will turn to matured pods while others cannot sustain (Jeyaraman, 2017). The unavailability of improved certified seeds leads the farmers to use poor seeds which ultimately reduces the yield (Bhingarde et al., 2015). Thus it is essential to supply quality certified seeds to growers to attain the stable yield. In seed production, due to its low seed multiplication ratio, five stages of seed production are permissible (Ntare et al., 2008). In groundnut, the matured pods normally contain 2-4 seeds. The single seeded pods also produced which is usually rejected in breeder seed production programme and these single seeded pods are usually used for confectionary purposes. The presence of single seeded pods in each groundnut plant ranges from 4-5 which accounts about $250-300 \mathrm{~kg} / \mathrm{ha}$. The formation of single seeded pod is due to the abortion of ovules present in the proximal end. These pods are difficult to decorticate using decorticator. (Karthick et al., 2018) recorded that the electrically powered groundnut sheller failed to decorticate single seeded pods and pods with two 
small seeds. They remain unshelled or partially shelled. Keeping view all the above points the present study was programmed to utilize these genetically pure single seeded pods for cultivation with suitable enhancement technique and sowing without shelling as labour saving technology.

\section{MATERIALS AND METHODS}

The laboratory study was conducted at the Department of Seed Science and Technology, Tamilnadu Agricultural University, Coimbatore. The pods of groundnut cv. CO 2 obtained from Agriculture Research Station, Bhavanisagar, Tamilnadu were separated and graded to conduct the experiment. The graded single seeded pods were subjected to following soaking treatments viz., pod without soaking as control, pod soaked in water, pod soaked in $0.5 \%$ calcium chloride, pod soaked in $1 \%$ calcium chloride, pod soaked in $2 \%$ calcium chloride, pod soaked in ethrel $200 \mathrm{ppm}$, pod soaked in ethrel $400 \mathrm{ppm}$ for durations of $12 \mathrm{hrs}$, $24 \mathrm{hrs}$ and $36 \mathrm{hrs}$. The pod to solution ratio of 1:1 on volume basis was followed for all the treatments. The pods were shade dried after soaking period and sown in sand mediun under laboratory condition without shelling. As the seeds were sown without shelling, it required more time to germinate. Thus the seedling evaluation was carried out on the 14th day after sowing. The germination per cent, seedling length, dry matter production, vigour index I (based on seedling length) and vigour index II (based on dry matter production) were calculated as prescribed by ISTA, 2013. The results were analysed in Completely Randomised Design with four replications.

\section{RESULT AND DISCUSSIONS}

The result disclosed that, there was a significant difference in the soaking treatment with water, calcium chloride and ethrel at various concentrations than control (pod without soaking) in all the tested parameters. The pods that were undergone different soaking treatments started to germinate at $5^{\text {th }}$ day after sowing where as control germinated at $7^{\text {th }}$ day after sowing.

Among various duration of water soaking treatment, the highest germination per cent (78\%) was recorded in pods soaked in water for $36 \mathrm{hrs}$ followed by 24 and $12 \mathrm{hrs}$. The least germination per cent was recorded in the control (70\%). The superiority continued for vigour index also. The pods soaked in water for $36 \mathrm{hrs}$ showed higher vigour index I (2613) and vigour index II (993). There was a significant difference in speed of germination, seedling length and dry matter production for pods soaked in water for $36 \mathrm{hrs}$ (Table 1). The similar result was concluded by Dubey et al., 2004. The soaking durations of pods in water for $36 \mathrm{hrs}$ and $48 \mathrm{hrs}$ enhanced the rate of seedling emergence. Kaul, 1999 observed that under field condition, the performance of sowing of water soaked pods were similar to that of farmers practice (kernel sowing). This clearly manifest that the higher soaking duration might have softened the shell and enabled the kernels to hydrate which facilitated better performance over control.

For different concentration and soaking durations of $\mathrm{CaCl}_{2}$, the peak germination per cent (90\%) was recorded in pods soaked in $1 \% \mathrm{CaCl}_{2}$ for $36 \mathrm{hrs}$ followed by $1 \% \mathrm{CaCl}_{2}$ for $24 \mathrm{hrs}$ whereas control recorded $70 \%$. The pods soaked in $0.5 \% \mathrm{CaCl}_{2}$ in all the durations recorded marked increase in germination over control. However the pods soaked in $2 \%$ $\mathrm{CaCl}_{2}$ registered reduction in germination per cent and seedling length in all the durations. The pods soaked in $1 \% \mathrm{CaCl}_{2}$ for $36 \mathrm{hrs}$ showed noticeable ranking in vigour index I (3656) and vigour index II (294) followed by $1 \% \mathrm{CaCl}_{2} 24$ hrs over control. The other parameters viz., speed of germination, seedling length and dry matter production were significantly higher in pods soaked in $1 \% \mathrm{CaCl}_{2}$ for $36 \mathrm{hrs}$ (Table 2). Generally for soaking the kernels $0.5 \% \mathrm{CaCl}_{2}$ is used. In the present study, higher concentration of $1 \% \mathrm{CaCl}_{2}$ was effective to enhance the physiological parameters since the pods were 
used instead of kernels. However, the pods soaked in $2 \% \mathrm{CaCl}_{2}$ registered reduced seed germination due to higher concentration.

Among various concentration and duration of soaking for ethrel, the maximum germination per cent (84\%) was recorded in pods soaked in ethrel 400ppm for $24 \mathrm{hrs}$ followed by pods soaked in ethrel 400ppm for $12 \mathrm{hrs}$ and $200 \mathrm{ppm}$ for 12 and 24 hrs. Its superiority was continued for vigour index I (3217) and vigour index II (265) also. The same trend was observed in speed of germination, seedling length and dry matter production (Table 3). These were evidenced by Ntare et al., 2008. An exogenous application of ethepon or ethrel releases the dormancy and induces germination in seeds of groundnut.

In the present study, the single seeded pods were soaked in water, $\mathrm{CaCl}_{2}(0.5 \%, 1 \%$ and $2 \%)$ and ethrel (200ppm and 400ppm) for 12, 24 and 36 hrs. The pod without soaking was kept as control. The pods were sown without shelling and physiological parameters were observed. The different soaking treatments showed marked differences than control.

After obtaining the best treatments through standardization from each of the solutions viz., water, $\mathrm{CaCl}_{2}$ and ethrel separately, another experiment was conducted with the best treatments of each experiment viz., soaking in water for 36 hrs, $1 \% \mathrm{CaCl}_{2}$ for $36 \mathrm{hrs}$ and ethrel $400 \mathrm{ppm}$ for $24 \mathrm{hrs}$ in order to get maximum seed quality characters.

Testing the effect of soaking treatments on germination per cent and vigour index I recorded that the pods soaked in $1 \% \mathrm{CaCl}_{2}$ for $36 \mathrm{hrs}$ ranked high followed by pods soaked in ethrel $400 \mathrm{ppm}$ for $24 \mathrm{hrs}$ and water soaking for $36 \mathrm{hrs}$. The same pattern was followed in seedling length, dry matter production, speed of germination and vigour index II (Figure 1). The germination per cent was increased to 17.1 percent in water soaked pods for 36 hrs, 28.6 per cent with $1 \%$ $\mathrm{CaCl}_{2}$ for $36 \mathrm{hrs}$ and $24 \%$ when pods soaked in ethrel 400ppm for 24 hrs over control. The results clearly showed that there was a strong relationship between calcium and seed germination. The calcium helps the seed by catalyzing the enzyme needed for germination. The results are in line with the reports of Arjunan et al.,1989 who documented that the groundnut seeds hardened with $1 \% \mathrm{CaCl}_{2}$ significantly increased pod yield by better germination per cent, dry matter accumulation and higher podsper plant. Christiansen et al., 1979 reported that the seeds primed with $0.5 \% \mathrm{CaCl}_{2}$ showed satisfactory result due to the role of calcium in membrane integrity. Assefa, 2008 stated that, the priming of seeds with $\mathrm{CaCl}_{2}$ showed earlier flowering and it is due to the effect of quicker germination of seeds. The soybean seeds primed with $0.5 \% \mathrm{CaCl}_{2}$ was ranked high in all yield parameters viz., plant height, number of branches, number of pods per plant, number of seeds per pods and seed yield per hectare(Chavan et al., 2014).

\section{CONCLUSIONS}

From the present study, it can be concluded the single seeded pods of groundnut which are rejected during seed production programme and those escaped from shelling can be effectively utilized for seed purpose without shelling by impairing invigoration treatments. The soaking treatment helps the kernel to germinate by facilitating easy breaking of the shell and improves all physiological parameters. The maximum beneficiary effect can be obtained from single seeded pods soaked in $1 \% \mathrm{CaCl}_{2}$ for $36 \mathrm{hrs}$. 


\section{REFERENCES}

1. Arjunan, A. \& Srinivasan, P.S. (1989). Pre-sowing seed hardening for drought tolerance in groundnut (Arachis hypogaea L.). Madras Agricultural Journal.76(9), 523-526.

2. Assefa, M. K. (2008). Effect of seed priming on storability, seed yield and quality of Soybean (Glycin max L. Merril)(unpublished M. Sc.Thesis), University of Agricultural Sciences, Dharwad, India,

3. Bhingarde, M.T, Kadam, R.S, \& Tagad, L.N. (2015). Effect of seed priming on seed yield and seed quality of groundnut (Arachis hypogaea l.). Life sciences international Research Journal. 2(3), 25-29.

4. Ali, W. D. A., Khudair, Z. W., \& Abed, M. J. Histopathological Changes in Male Rabbits Thyroid Gland Following Drenching of Nickel Chloride and the Ameliorating Effect of Ethanolic Silybum Marianum Seeds Extract.

5. Chavan, N.G, Bhujbal, G.B, \& Manjare, M.R. (2014). Effect of seed priming on field performance and seed yield of soybean [Glycine max (l.) Merill] varieties. The bioscan. 9(1), 111-114.

6. Christiansen, M.N, \& Foy, C.D. (1979). Fate and function of calcium in tissue. Communications in Soil Science and Plant Analysis.10(1-2), 427-442.

7. Dubey, R. K, Kauu, J.N, \& Kaurj, N. (2004). Effect of plant geometry and water soaking duration of pod on summer groundnut (Arachis hypogaea). Indian journal of Agricultural Sciences. 74 (7), 392-393.

8. ISTA. International rules for seed testing. Seed Sci.Technol. Supplement Rules: 2013,27-57.

9. Abid-Ali, W. D. The Effect of Silymarine Extracted from Silibum Marianum Seeds on Histopathological Changes in Male Rabbits Liver and Kidney induced by Nickel Chloride Toxicity.

10. Jeyaraman, S. (2017). Field crops production and management. Vol. II, New Delhi:Oxford \& IBH Publishing CO. PVT. Ltd.

11. Singh, D., \& Sharma, N. (2017). Effect of chromium on seed germination and seedling growth of green garm (Phaseols Aureus L) and chickpea (Cicer Arietinum L). Int J App Nat Sci, 6, 37-46.

12. Karthik, G, Balashankar, D, Rambabu, G, Nagabhushanam, B, Akhil, L, \& Lakshumu Naidu, A.(2018).Design and Fabrication of Groundnut Pods and Shell Stripper. International Journal of Engineering Trends and Technology. 58(2). 60-64.

13. Kaul, J.N. (1999). Preliminary studies on emergence of two groundnut varieties in relation to pod vs kernel sowing with and without water soaking. Data presented at the group meeting on groundnut sponsored by zonal coordinating unit zonal - 1 , transfer of technology projects (ICAR) Punjab agricultural university, Ludhiana.

14. Meshram, R., \& Chaturvedi, A. (2017). Effect of insecticide on in vitro pollen germination of Lycopersicon esculentum (Mill.) of F1 hybrid variety Laxmi. Int. J. Appl. Nat. Sci, 6(4), 01-10.

15. Nigam, S.N. (2000).Some strategic issues in breeding for high and stable yield in groundnut in India. Journal of Oilseeds Research. 17(1), 1-10.

16. Ntare, B. R, Diallo, A. T, Ndjeunga, J, \& Waliyar, F. (2008).Groundnut Seed production Manual. Patancheru 502 324, Andhra Pradesh, India: International Crops Research Institute for the Semi-Arid Tropics (ICRISAT), 3-4. 


\section{APPENDIX}

Table 1: Effect of Soaking Treatment with Water on Physiological Parameters on Single Seeded Pods of Groundnut Cultivar cv. CO 2

\begin{tabular}{|l|c|c|c|c|c|c|}
\hline \multicolumn{1}{|c|}{$\mathbf{T}$} & $\begin{array}{c}\text { Speed of } \\
\text { Germination }\end{array}$ & $\begin{array}{c}\text { Germination } \\
(\mathbf{\%})\end{array}$ & $\begin{array}{c}\text { Seedling } \\
\text { Length } \\
(\mathbf{c m})\end{array}$ & $\begin{array}{c}\text { Dry Matter } \\
\text { Production } \\
(\mathbf{g} / \mathbf{1 0 s e e d l i n g s )}\end{array}$ & $\begin{array}{c}\text { Vigour } \\
\text { Index } \\
\text { I }\end{array}$ & $\begin{array}{c}\text { Vigour } \\
\text { Index } \\
\text { II }\end{array}$ \\
\hline $\mathrm{T}_{1}$ & 1.50 & $70(56.79)$ & 29.5 & 2.21 & 2087 & 156 \\
\hline $\mathrm{T}_{2}$ & 2.00 & $78(62.02)$ & 32.6 & 2.87 & 2537 & 223 \\
\hline $\mathrm{T}_{3}$ & 2.05 & $80(63.43)$ & 34.5 & 2.90 & 2740 & 231 \\
\hline $\mathrm{T}_{4}$ & 2.50 & $82(64.89)$ & 37.6 & 3.08 & 3088 & 254 \\
\hline Mean & $\mathbf{2 . 0 1}$ & $\mathbf{7 8 ( 6 2 . 0 2 )}$ & $\mathbf{3 3 . 6}$ & $\mathbf{2 . 7 7}$ & $\mathbf{2 6 1 3}$ & $\mathbf{2 1 6}$ \\
\hline $\mathrm{SEd}$ & 0.047 & 0.8 & 0.44 & 0.043 & 32.4 & 3.6 \\
\hline $\mathrm{CD}(\mathrm{P}=0.05)$ & 0.104 & 1.8 & 0.97 & 0.093 & 70.6 & 7.8 \\
\hline
\end{tabular}

(Figures in parenthesis indicates arcsine values)

Treatments (T): $\mathrm{T}_{1}-$ Control, $\mathrm{T}_{2}-12 \mathrm{hrs}, \mathrm{T}_{3}-24 \mathrm{hrs}, \mathrm{T}_{4}-36 \mathrm{hrs}$

Table 2: Effect of Soaking Treatment with Calcium Chloride on Physiological Parameters on Single Seeded Pods of Groundnut Cultivar cv. CO 2

\begin{tabular}{|l|c|l|c|c|c|c|}
\hline $\mathbf{T}$ & $\begin{array}{l}\text { Speed of } \\
\text { Germination }\end{array}$ & $\begin{array}{l}\text { Germination } \\
(\boldsymbol{\%})\end{array}$ & $\begin{array}{l}\text { Seedling } \\
\text { Length }(\mathbf{c m})\end{array}$ & $\begin{array}{l}\text { Dry } \\
\text { production } \\
\text { (g/10seedlings) }\end{array}$ & $\begin{array}{l}\text { Matter } \\
\text { index } \\
\text { I }\end{array}$ & $\begin{array}{l}\text { Vigour } \\
\text { index } \\
\text { II }\end{array}$ \\
\hline $\mathrm{T}_{1}$ & 1.50 & $70(56.79)$ & 29.6 & 2.21 & 2086 & 156 \\
\hline $\mathrm{T}_{2}$ & 2.59 & $62(51.94)$ & 35.4 & 2.28 & 2192 & 142 \\
\hline $\mathrm{T}_{3}$ & 2.73 & $72(58.05)$ & 37.1 & 2.34 & 2671 & 169 \\
\hline $\mathrm{T}_{4}$ & 2.77 & $74(59.34)$ & 37.1 & 2.39 & 2742 & 177 \\
\hline $\mathrm{T}_{5}$ & 2.79 & $70(56.70)$ & 36.7 & 2.43 & 2571 & 170 \\
\hline $\mathrm{T}_{6}$ & 2.88 & $82(64.89)$ & 37.7 & 2.90 & 3090 & 238 \\
\hline $\mathrm{T}_{7}$ & 3.13 & $90(71.56)$ & 40.6 & 3.26 & 3656 & 294 \\
\hline $\mathrm{T}_{8}$ & 2.20 & $58(49.60)$ & 33.8 & 2.18 & 1970 & 127 \\
\hline $\mathrm{T}_{9}$ & 1.90 & $57(49.02)$ & 33.5 & 2.10 & 1900 & 120 \\
\hline $\mathrm{T}_{10}$ & 1.50 & $55(47.87)$ & 32.8 & 2.02 & 1810 & 112 \\
\hline Mean & $\mathbf{2 . 4 0}$ & $\mathbf{6 9}$ & $\mathbf{3 5 . 4}$ & $\mathbf{2 . 4 2}$ & $\mathbf{2 4 6 9}$ & $\mathbf{1 7 1}$ \\
\hline $\mathrm{SEd}$ & 0.094 & 0.7 & 0.59 & 0.036 & 36.6 & 2.5 \\
\hline $\mathrm{CD}(\mathrm{P}=0.05)$ & 0.193 & 1.5 & 1.21 & 0.074 & 74.7 & 5.2 \\
\hline
\end{tabular}

(Figures in parenthesis indicates arcsine values)

Treatments(T): $\mathrm{T}_{1}-$ Control, $\mathrm{T}_{2}-0.5 \%$ for $12 \mathrm{hrs}, \mathrm{T}_{3}-0.5 \%$ for $24 \mathrm{hrs}, \mathrm{T}_{4}-0.5 \%$ for $36 \mathrm{hrs}, \mathrm{T}_{5}-1 \%$ for $12 \mathrm{hrs}$, $\mathrm{T}_{6}-1 \%$ for $24 \mathrm{hrs}, \mathrm{T}_{7}-1 \%$ for $36 \mathrm{hrs}, \mathrm{T}_{8}-2 \%$ for $12 \mathrm{hrs}, \mathrm{T}_{9}-2 \%$ for $12 \mathrm{hrs}, \mathrm{T}_{10}-2 \%$ for $12 \mathrm{hrs}$

Table 3: Effect of Soaking Treatment with Ethrel on Single Seeded Pods of Groundnut Cultivar cv. CO 2

\begin{tabular}{|l|c|c|c|c|c|c|}
\hline \multicolumn{1}{|c|}{$\mathbf{T}$} & $\begin{array}{c}\text { Speed of } \\
\text { Germination }\end{array}$ & Germination $(\boldsymbol{\%})$ & $\begin{array}{c}\text { Seedling } \\
\text { Length } \\
(\mathbf{c m})\end{array}$ & $\begin{array}{c}\text { Dry Matter } \\
\text { Production } \\
(\mathbf{g} / \mathbf{1 0 s e e d l i n g s})\end{array}$ & $\begin{array}{c}\text { Vigour } \\
\text { Index } \\
\text { I }\end{array}$ & $\begin{array}{c}\text { Vigour } \\
\text { Index } \\
\text { II }\end{array}$ \\
\hline $\mathrm{T}_{1}$ & 1.50 & $70(56.79)$ & 29.2 & 2.21 & 2086 & 156 \\
\hline $\mathrm{T}_{2}$ & 2.57 & $78(62.02)$ & 31.3 & 2.31 & 2443 & 180 \\
\hline $\mathrm{T}_{3}$ & 2.63 & $78(62.02)$ & 33.3 & 2.54 & 2595 & 198 \\
\hline $\mathrm{T}_{4}$ & 2.71 & $76(60.66)$ & 36.9 & 2.87 & 2801 & 219 \\
\hline $\mathrm{T}_{5}$ & 2.82 & $78(62.02)$ & 35.5 & 2.77 & 2770 & 217 \\
\hline $\mathrm{T}_{6}$ & 2.90 & $84(66.42)$ & 38.1 & 3.13 & 3217 & 265 \\
\hline $\mathrm{T}_{7}$ & 2.76 & $77(61.34)$ & 34.3 & 2.52 & 2644 & 194 \\
\hline Mean & $\mathbf{2 . 5 6}$ & $\mathbf{7 7}(\mathbf{6 1 . 3 4})$ & $\mathbf{3 4 . 1}$ & $\mathbf{2 . 6 3}$ & $\mathbf{2 6 4 9}$ & $\mathbf{2 0 4}$ \\
\hline $\mathrm{SEd}$ & 0.035 & 0.6 & 0.44 & 0.037 & 30.0 & 2.8 \\
\hline $\mathrm{CD}(\mathrm{P}=0.05)$ & 0.073 & 1.3 & 0.92 & 0.077 & 62.4 & 5.9 \\
\hline
\end{tabular}

(Figures in parenthesis indicates arcsine values)

Treatments(T): $\mathrm{T}_{1}-$ Control, $\mathrm{T}_{2}-200 \mathrm{ppm}$ for $12 \mathrm{hrs}, \mathrm{T}_{3}-200 \mathrm{ppm}$ for $24 \mathrm{hrs}, \mathrm{T}_{4}-200 \mathrm{ppm}$ for $36 \mathrm{hrs}$, $\mathrm{T}_{5}-400 \mathrm{ppm}$ for $12 \mathrm{hrs}, \mathrm{T}_{6}-400 \mathrm{ppm}$ for $24 \mathrm{hrs}, \mathrm{T}_{7}-400 \mathrm{ppm}$ for $36 \mathrm{hrs}$ 

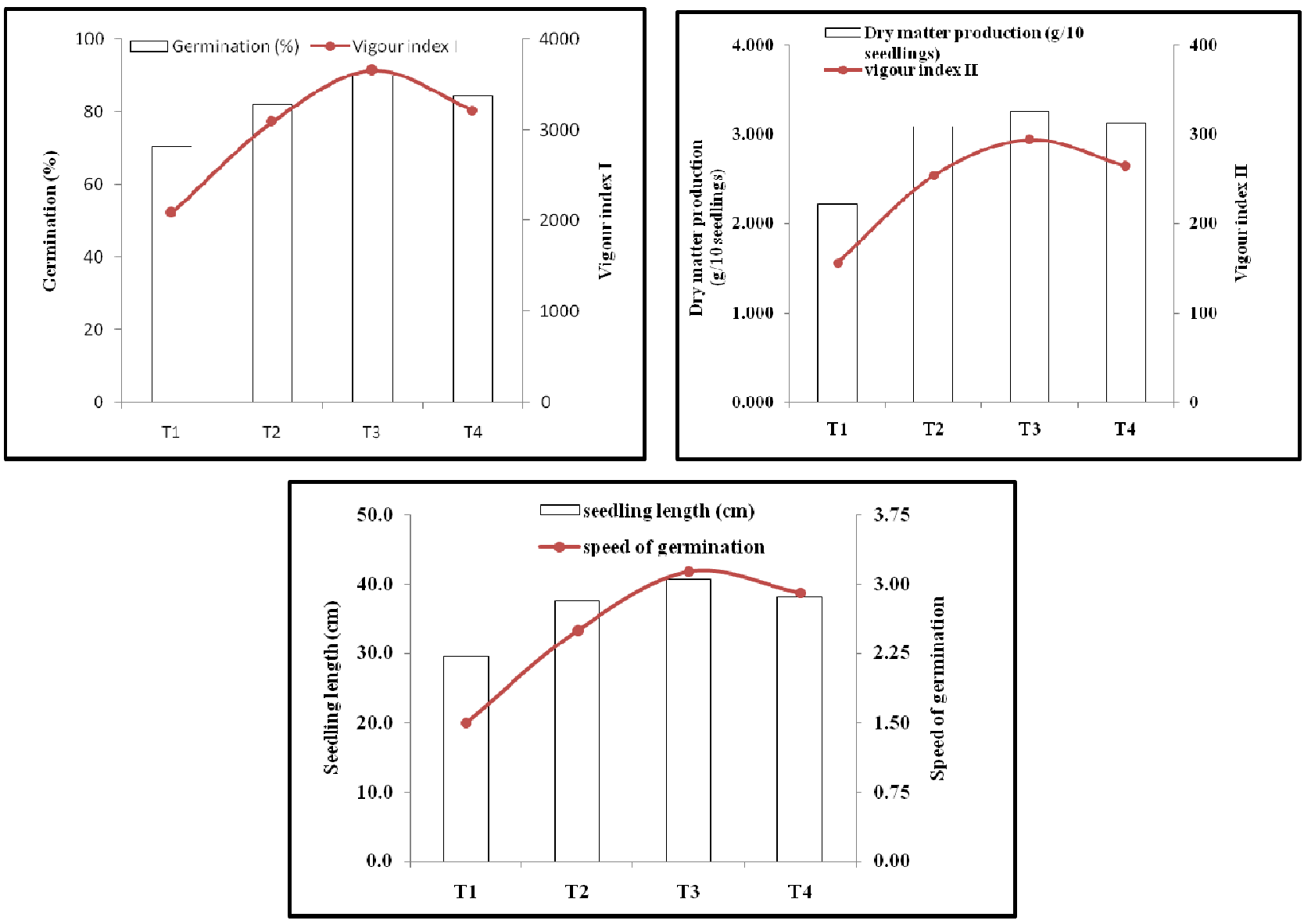

Treatments (T); $\mathbf{T}_{1}-$ Control, $\mathrm{T}_{2}-$ Water for $36 \mathrm{hrs}$,

$T_{3}-1 \%$ Calcium chloride for $36 \mathrm{hrs}, T_{4}-$ Ethrel 400ppm for $24 \mathrm{hrs}$

Figure 1: Effect of Different Soaking Treatments on Germination per cent and Vigour Index I of Single Seeded Pods of Groundnut cv. CO 2 